\title{
Disparidades entre realidade e representação: a percepção das mulheres sobre a publicidade de cerveja
}

\author{
Disparities between reality and representation: women's perception \\ on beer advertisement
}

\section{Renata Barreto Malta}

Professora Efetiva do Departamento de Comunicação Social - Publicidade e Propaganda. Professora permanente do curso de Pós-graduação em Comunicação da Universidade Federal de Sergipe (PPGCOM - UFS). Doutora em Comunicação Social pela Universidade Metodista de São Paulo. Pós-doutorado em andamento na Universidad de Sevilla.

\section{Kívia Monique Rodrigues Da Silva}

Graduada em Comunicação Social com habilitação em Publicidade e Propaganda pela Universidade Federal de Sergipe.

\section{RESUMO}

Este artigo tem como objetivo compreender a percepção de mulheres acerca da representação feminina nos comerciais de cerveja brasileiros. Partimos da premissa que a publicidade é parte do sistema simbólico de representação e expressa valores sociais. Para a pesquisa empírica, definimos um corpus tendo como referência o estudo de Malta e Silva (2016), composto por peças publicitárias de marcas de cerveja. Este conteúdo é mediador de uma Pesquisa de Recepção com mulheres jovens, considerando também as variáveis "classe social" e "raça". Em suma, chegamos a conclusões acerca da percepção de papéis de gênero, raça e classe no conteúdo apresentado. As representações estereotipadas são instantaneamente reconhecidas e rechaçadas e, ainda que a maioria das produções não retrate a mulher como consumidora do produto, esta, em geral, se autodeclara consumidora e independente.

Pallavras-chave: Representação; Gênero; Pesquisa de Recepção; Publicidade de cerveja.

$$
223
$$




\section{ABSTRACT}

This article aims to verify women's perception regarding female representation in Brazilian advertisements of beer. We start from the premise that advertising is part of the symbolic system of representations and it expresses social values. For the empirical research, we have defined a corpus having as a reference the study of Malta and Silva (2016) on beer advertising. This content is the mediator in an Audience Research with young women in which the variables "social class" and "race" have also been considered. Briefly, we have reached some conclusions about the perception of gender, race, and class roles in the corpus. Stereotyped representations are instantaneously recognized and rejected and, although most of the productions don't portray women as consumers of the product, they in general, declare themselves consumers and independent.

Keywords: Representation; Gender; Audience Research; Beer advertising.

\section{RESUMEN}

Este artículo tiene como objetivo comprender la percepción de las mujeres acerca de la representación femenina en los anuncios de cerveza brasileños. Partimos de la premisa que la publicidad es parte del sistema simbólico de representación y expresa valores sociales. Para la investigación empírica, definimos un corpus teniendo como referencia el estudio de Malta e Silva (2016), compuesto por publicidades de marcas de cerveza. Este contenido es mediador de un Estudio de Recepción con mujeres jóvenes, considerando también las variables "clase social" y "raza". Resumidamente, llegamos a conclusiones acerca de la percepción de roles de género, raza y clase en el contenido presentado. Las representaciones estereotipadas son instantáneamente reconocidas y rechazadas $\mathrm{y}$, aunque la mayoría de las producciones no retraten la mujer como consumidora del producto, ella, por lo general, se auto declara consumidora e independiente.

Pallalbras-clave: Representación; Género; Estudio de Recepción; Publicidad de cerveza.

\section{Introdução}

Este artigo propõe uma discussão acerca da representação da mulher em comerciais de cerveja brasileiros e sua contextualização sociocultural. A cultura é aqui compreendida como um ambiente de disputa e relações de poder. Segundo Hall (2003), as diferenças alicerçam essa arena, as quais são formadas por certas estruturas: econômica, política e ideológica. Assim, todos os sistemas simbólicos que permeiam os indivíduos em sua cultura acabam construindo, de alguma maneira, a sua identidade. 
A compreensão da publicidade como produto cultural e a relevância de suas representações como parte do sistema simbólico é premissa deste estudo. Esses sistemas produzem significados quando pessoas são representadas e identidades associadas ao universo do consumo, funcionando como ícones a serem reconhecidos e propagados como modelos sociais, formando, ou deformando, o imaginário coletivo. Para Kellner, a propaganda vende estilos de vida e identidades socialmente desejáveis e "os publicitários utilizam construtos simbólicos, com os quais o consumidor é convidado a identificar-se para tentar induzi-lo a usar o produto anunciado" (Kellner, 2001, p. 324). As contribuições de Piedras (2005) também seguem nessa direção.

O fato de a publicidade ter como principal função a divulgação de bens e serviços com o objetivo de gerar vendas e reproduzir o modo de produção capitalista, não exclui sua dimensão cultural, que constrói representações sociais e atualiza o imaginário contemporâneo, além de contribuir para criar ou reafirmar práticas (Piedras, 2005, p. 62).

Por meio das diversas representações que são comunicadas pela propaganda, indivíduos interpretam a mensagem/o discurso com certa familiarização. Conforme Everardo Rocha, "a mensagem tem que falar a nossa língua, seus habitantes, no mais das vezes, se parecem fisicamente conosco ou pelo menos com alguns de nós” (Rocha, 1990, p.194). Podemos questionar as asserções de Rocha ao trazermos para a discussão o conceito de "tipicalidade" interpretado por Williams (1979), a partir de duas perspectivas distintas. A primeira entende o tipo "ideal" como "personagens universais". A associação dos "universais" ao idealismo, em um sentido secular, é direta. Uma ênfase bastante distinta relaciona o "típico" ao plenamente característico ou representativo, uma figura específica a qual concentra uma realidade muito mais geral. Assim, quando Rocha afirma que os habitantes do mundo da publicidade se parecem fisicamente "conosco" ou pelo menos com alguns de nós, ele provavelmente se refere ao "típico" como representativo ou característico. De fato, o reconhecimento por parte do público é uma premissa do discurso publicitário; no entanto, é comum, nesse universo, que o "tipo ideal" se sobreponha ao "típico", representando não uma figura real e geral, mas um modelo idealizado sob a perspectiva hegemônica. Neste contexto, a publicidade pode ser considerada uma forma de mediação de valores que estão no construto social. 
É nessa suposta negociação que focaremos nosso olhar. Assim, a pergunta que orienta esta pesquisa se resume em: "em que medida este construto social, dinâmico e mutante se reflete nas interpretações de mulheres jovens brasileiras receptoras ao serem expostas às representações da mulher na publicidade de cerveja"?

Para respondê-la, propomos uma pesquisa de recepção com mulheres jovens da cidade de Aracaju (SE) e, por acreditarmos que as relações de poder baseadas no gênero se interseccionam a raça e classe social, consideramos estas variáveis para a seleção das respondentes. As diretrizes para a realização da pesquisa serão explicitadas no tópico seguinte.

\section{Metodologia}

Como método, propomos uma Pesquisa de Recepção a partir de um corpus selecionado com base em estudo publicado por Malta e Silva (2016). Nele, por meio da Análise de Conteúdo de peças publicitárias audiovisuais produzidas para o setor de cerveja, criteriosamente selecionadas, chegou-se a modelos de representação da mulher, os quais podem ser descritos em temáticas (Quadro 1). Considerando tais categorias, a pesquisa apresentou uma análise descritiva dos dados, com o intuito de mensurar quais temáticas apareciam com mais e menos frequência no conteúdo analisado.

Quadro 1: Representação percentual da categorização das imagens femininas identificadas nos comerciais de cerveja.

\begin{tabular}{|l|c|c|c|c|c|c|c|}
\hline Categoria & Coadjuvante & $\begin{array}{c}\text { Escrava/ } \\
\text { Serviçal }\end{array}$ & Objeto & Protagonista & Sedutora & $\begin{array}{c}\text { Segundo } \\
\text { Plano }\end{array}$ & $\begin{array}{c}\text { Igualdade } \\
\text { de } \\
\text { Condições }\end{array}$ \\
\hline Porcentagem & 14,28 & 5,71 & 37,14 & 2,85 & 34,28 & 8,57 & 31,42 \\
\hline
\end{tabular}

Fonte: Malta e Silva (2016) 
Assim, partindo desses dados já previamente publicados, o presente artigo propõe uma pesquisa de recepção com a finalidade de compreender a percepção das mulheres acerca desse conteúdo, especificamente mulheres jovens - de 18 a 29 anos - e da cidade de Aracaju. Ressaltamos que a seleção dos comerciais se baseou no corpus publicado em Malta e Silva (2016) e que essas produções foram veiculadas entre os anos de 2004 e 2013, seguindo critérios definidos pelas autoras ora citadas.

Segundo Antônio Carlos Ruótulo, este tipo de estudo busca entender a resposta do receptor acerca de um determinado conteúdo após a sua exposição a um meio. 0 autor afirma que, aqui, a audiência é compreendida como uma prática social com baixo grau de envolvimento e realizada de forma não estruturada. Nas palavras do autor,

\begin{abstract}
Este caráter de pano de fundo da vida quotidiana é um aspecto central de todas as perspectivas de recepção porque só assim (entendendo-se a exposição como algo automático e secundário) pode ser compatibilizado o fato dos meios (especialmente da televisão) serem tão populares e amplamente apreciados pelos receptores, mesmo trazendo conteúdos que muitas vezes são considerados (pelos teóricos da recepção) como contrários aos interesses do receptor (Ruótulo, 1998, p.154).
\end{abstract}

Nosso interesse com este estudo está em observar, após a exposição, a reconstrução dos significados realizada pelas receptoras dentro de seu próprio contexto, partindo da premissa de que a audiência é ativa e atribui significados aos conteúdos de acordo com sua realidade sociocultural. A esse respeito, Ruótulo (1998) afirma que "não existe interpretação única; cada receptor, cada comunidade encontra significados que se aproximam mais de si mesmos do que do emissor" (Ruótulo, 1998, p.150).

Essas interpretações ocorrem em consequência de uma série de mediações (classe social, etnia, faixa etária, escolaridade, gênero, crenças religiosas, entre outras). Michel de Certeau (1998) nos alerta que o cotidiano merece uma atenção maior como mediador das interpretações dos receptores, já que a percepção dos mesmos está ligada aos seus valores, comportamentos, tradições, vida prática.

Considerando nossa intenção em compreender as percepções de um grupo específico de receptores, delimitamos que este seria formado por mulheres jovens - o 
Estatuto da Juventude abarca pessoas entre 15 a 29 anos, porém, por ser a cerveja um produto voltado para maiores de 18 anos, definimos esta a idade mínima das entrevistadas.

Ademais, por uma questão de viabilidade da pesquisa e interesse em trabalhar com receptoras na região Nordeste do Brasil, decidimos que a restringiríamos a jovens da cidade de Aracaju, Sergipe ${ }^{3}$. Por entendermos que outros aspectos sociais possam ser relevantes, decidimos separar as entrevistadas em classe social e grupo racial. No total, foram quatro as entrevistadas de cada grupo: 1- mulheres jovens, brancas de classe A ou B; 2- mulheres jovens não brancas de classe A ou B; 3- mulheres jovens brancas de classe C ou D e 4- mulheres jovens não brancas de classes C e D. Para a identificação da classe social, na fase de seleção das entrevistadas, aplicamos o questionário socioeconômico da ABEP.

Para a definição dos grupos raciais, partimos da concepção defendida por Hall (2003), uma construção social e política, baseada em atributos fenotípicos, mas determinada pela relação de poder entre grupos raciais e pelas vivências culturais e simbólicas. Nessa relação de poder, em sociedades onde o racismo se faz presente, como na brasileira, observamos a separação entre dominantes e dominados, privilegiados e não privilegiados. Assim, entendemos ser a raça branca hegemônica e dominante e, as demais, minorias (menos privilegiadas), justificando nossa escolha no que concerne à delimitação racial dos grupos, sempre a partir da autodeclaração.

Para a seleção do corpus a ser exibido ao longo da pesquisa de recepção, extraímos do estudo anteriormente mencionado, publicado por Malta e Silva (2016), um comercial representativo de cada categoria, presente no quadro 1. Assim, expusemos às 16 mulheres entrevistadas esse conteúdo e realizamos uma entrevista em profundidade

\footnotetext{
3 Este recorte se justifica porque na região Nordeste encontramos altos índices de violência contra a mulher, fruto do machismo fortemente aculturado. Segundo pesquisa realizada pela Universidade Federal do Ceará em parceria com o Instituto Maria da Penha (ONU MULHERES, 2017), 27\% das mulheres nordestinas se declararam vítimas de violência de gênero. As capitais com maior incidência foram Maceió $(\mathrm{AL})$, Recife (PE) e Aracaju (SE).
} 
com cada uma delas, baseada em perguntas semelhantes após a exibição de cada produção audiovisual, em sete blocos - cada bloco era iniciado com um vídeo.

Pontuamos que as entrevistas foram realizadas seguindo um roteiro semiestruturado com perguntas abertas, com o intuito de recolher de forma aprofundada e qualitativa a interpretação da entrevistada, já que esta técnica "não permite testar hipóteses, tratar estatisticamente as informações, definir a amplitude ou a quantidade de um fenômeno" (Duarte, 2006, p. 62). Assim, os resultados aqui apresentados não são generalizáveis como aqueles que proporcionam métodos quantitativos; no entanto, seu caráter propicia a compreensão de um fenômeno a partir de diferentes perspectivas. Bauer e Gaskell (2002) afirmam que esta técnica é um convite ao entrevistado a se alongar, explorando várias percepções. Os autores recomendam um número aproximado de 15 a 20 entrevistas, considerando que o objetivo do método é buscar aprofundamento e não uma seleção superficial de dados. Seguindo a recomendação dos autores, mesmo que poucos respondentes expressem uma percepção específica, ela deve ser considerada e evidenciada como relevante. Assim, na discussão dos resultados, procuraremos não quantificar a frequência das respostas, salvo em situações de total consenso ou dissenso, evitando relativizar tais percepções.

Na etapa de análise, fizemos uso do software HyperRESEARCH, com a intenção de sistematizar as respostas encontradas e facilitar sua interpretação. Deste processo, emergiram as seguintes categorias: "primeiras impressões"; "cotidiano"; "sentimento ao assistir ao comercial"; "consumidor do produto"; "perfil do homem"; "perfil da mulher" e "autorreconhecimento". Em uma etapa subsequente, comparamos os resultados já interpretados, sem a delimitação categórica, trazendo também aspectos raciais e de classe que ali se fizeram presentes. Considerando a limitação de páginas para este artigo e a relevância dos resultados comparativos, no tópico seguinte apresentaremos nossas conclusões acerca de cada comercial, representativo de uma temática específica.

\section{Resultados Comparativos: a representação de gênero em foco}


Pretendemos aqui realizar uma análise comparativa levando em consideração a percepção das entrevistadas acerca do conteúdo exposto. Assim, pontuaremos de forma sintética os critérios adotados para a codificação de cada temática, presentes em Malta e Silva (2016), e uma breve sinopse dos vídeos, para, então, focarmos nas semelhanças e discrepâncias do modo como as entrevistadas interpretaram o material apresentado.

\section{Comercial 1: Temática: "Coadjuvante”}

Para essa codificação, o critério adotado em Malta e Silva (2016) foi a percepção da mulher como figurante de atividades cujo protagonista é o homem. A peça "Skol Ilha Redond $4^{4 "}$, de 2004, é retrato desse tipo de representação. Nela, são apresentadas uma "Ilha Quadrada", onde aparecem homens "se divertindo" de maneira chata, e uma "Ilha Redonda", com várias pessoas dançando (homens e mulheres), surfando (homens), jogando futebol (homens); em uma dessas cenas, tanto o homem quanto a mulher aparecem segurando uma lata de cerveja, porém apenas o homem a bebe.

Ao ser exposto às respondentes, sua primeira impressão foi a constante relação da cerveja à diversão, vista, em geral, de forma positiva; alguns depoimentos, porém, citam a intenção da marca em colocar o homem no centro da narrativa, reforçando, criticamente, que esse discurso é recorrente. Observamos que especificamente as mulheres que se identificaram como "pardas" 5 ou negras - o qual denominamos "nãobrancas" - mencionam como primeira impressão a presença de mulheres bonitas e com corpos considerados "desejáveis" e expostos. A fala da entrevistada 1 - "não-branca" de classe C - é bastante ilustrativa: "Acho que esse comercial expõe mais a mulher com um perfil parecido, todas são bonitas, têm 'tipão', corpão e só os homens estão bebendo." Como primeira impressão, nenhuma entrevistada que se autodeclarou "branca" teve essa percepção no que concerne o corpo das modelos. Assim, podemos concluir que, ao menos nesses casos, a primeira impressão acerca de corpos tidos como ideais tem em

\footnotetext{
${ }^{4}$ Disponível em: https://www.youtube.com/watch?v=BpWgZea7jvc

5 Entendemos que o termo "parda" vem sendo desconstruído e rejeitado por movimentos sociais que lutam contra o racismo, no entanto, prezamos pela nomenclatura autodeclarada pelas entrevistadas.
} 
algum nível associação a aspectos étnico-raciais, considerando que essas mulheres não pertencem à raça hegemônica, reforçada pelo fato de todas as mulheres do comercial serem brancas.

Ao perguntarmos se o filme apresentado retrata o cotidiano das entrevistadas, essas, em geral, responderam que sim, narrando, principalmente, o consumo de cerveja associado à socialização. Notamos que algumas mulheres trazem experiências pessoais desse universo, ora afirmando que é comum haver mais homens do que mulheres em ambientes de diversão e de bebidas, ora problematizando a relação entre festa, bebida e comportamento masculino, apontando a bebida alcoólica como estímulo para o flerte e, de forma mais crítica, ao assédio. Parece-nos relevante pontuar que esse tipo de atitude masculina não estava explícito na narrativa, porém, por analogia e associação ao cotidiano, esses relatos se fizeram presentes. Como exemplo, a entrevistada 7 - "não branca", classe B - comenta que "o homem é protagonista e a mulher não desempenha papel nenhum, é só um aperitivo a mais, ela serve para os homens ficarem olhando, para ficarem cantando e nada mais".

Observamos que as mulheres entrevistadas, em geral, percebem o homem como consumidor da cerveja, pontuando que o produto parece ser "proibido" para o público feminino, já que não viu em nenhum momento mulheres degustando a cerveja.

\section{Comercial 2: Temática: "Escrava/Serviçal"}

Essa temática teve como critério de codificação a mulher subalterna ao homem, servindo-o de alguma maneira. Para esse modelo de representação selecionamos o comercial da cerveja Skol intitulado "Skol China ${ }^{6 ", ~ d e ~ 2010 . ~ N e s s a ~ p r o d u c ̧ a ̃ o, ~ u m ~ c o o l e r ~}$ de cervejas é puxado para dentro de um buraco (Brasil) que vai até o outro lado do mundo (China). Assim que as cervejas entram no buraco, homens brasileiros tentam salvá-las e são arrastados. Lá, do outro lado do mundo, fazem uma festa com a bebida.

\footnotetext{
${ }^{6}$ Disponível em: https://www.youtube.com/watch?v=44JbuzijCwI
} 
Em uma das cenas, que seria supostamente na China, um homem aparece deitado tomando cerveja em uma cadeira de praia, enquanto uma mulher o massageia.

Como resultado, após a exibição, a divisão de papeis de gênero foi percebida de forma negativa, apontando a diversão e o consumo para o homem e para a mulher a exposição do corpo e a exploração do trabalho. Identificamos também, por meio das entrevistas, a percepção de que a cerveja é um produto importante para os homens, sendo notório que o homem é o público-alvo do comercial. Observamos uma interpretação positiva acerca da relação da cerveja à diversão, reforçando a ideia de que os ambientes em que há o consumo se tornam mais alegres. Apontamos que as mulheres não brancas e brancas da classe CD relataram como primeira impressão a mulher serviçal. Como exemplos, a entrevistada 7 - "não branca" de classe B - inicialmente comenta: "ela tem que estar ali em pé fazendo massagem, e ela que se dane, tem que estar servindo a ele." Com conotação semelhante, a entrevistada 10 - branca de classe C - questiona: "mais uma vez ela sendo submissa ao homem. Por que eles estão bebendo cerveja e elas estão fazendo massagem neles?" Mulheres com os demais perfis não se manifestaram a esse respeito espontaneamente como primeira impressão. Podemos então pontuar que há uma relação de classe e de raça associada à questão do trabalho e subalternidade.

Apontamos aqui, de forma interseccional, o recorte de gênero, etnia e classe social como necessários para entender o papel dessa mulher e o seu lugar nas disputas de poder na sociedade; ao notarem rapidamente a representação da mulher serviçal, as mulheres das classes $\mathrm{C}$ e D demonstram que esse universo lhes é familiar. $\mathrm{O}$ feminismo interseccional, pensado por Kimberlé Crenshaw (2002), propõe investigar a rede de opressões que acometem a vida das mulheres ao invés de hierarquizá-las. Mesmo passados mais de um século da abolição da escravatura, a mulher negra permanece na base da pirâmide social e econômica do país (Marcondes et al., 2013).

Além do hábito de consumo da bebida, percebemos que a maioria das entrevistadas mencionou a divisão de papeis entre os gêneros como aspecto de seu cotidiano. Notamos, aqui, que as variáveis foram significativas. 0 assédio se mostrou 
mais perturbador para mulheres brancas e a exploração do trabalho para as mulheres "não brancas". Para a entrevistada 1 - "não branca", classe C - a relação do vídeo ao cotidiano se expressa em: "ela não se diverte em nenhum momento, ela só tem que estar ali para fazer as coisas, trabalhando". Ao associar o conteúdo e o cotidiano, a entrevistada 12 - branca, classe B - comenta: “a cerveja, ela socializa. Numa roda de bebidas tem muita descontração, paquera, mas tem homem que abusa".

Esse tema é estudado por feministas como bell hooks e Claudia Pacheco (2013). Segundo Pacheco, no conjunto de mulheres, ainda é a negra a mais preterida e a sua solidão é resultado de uma sociedade racista e machista, que acultura e naturaliza padrões estéticos e comportamentais, de forma excludente e segregacionista. 0 assédio é uma das facetas do machismo e se mostra opressor, como vimos nos depoimentos, porém ao identificá-lo como mais recorrente entre as brancas, entendemos que para além de gênero existe uma intersecção racial relevante. Angela Davis (1997) faz uma análise sobre essas intersecções categóricas.

\footnotetext{
Raça é a maneira como a classe é vivida. Da forma que gênero é a maneira como a classe é vivida. A gente precisa refletir bastante para perceber que entre essas categorias existem relações que são mútuas e outras que são cruzadas. Ninguém pode assumir a primazia de uma categoria sobre as outras (Davis, 1997, p.8).
}

Para além dessa discussão, outros comentários muito se assemelharam àqueles apresentados no vídeo anterior, acerca da objetificação do corpo da mulher e da ausência de identificação por parte das entrevistadas no que concerne esse modelo de representação.

\section{Comercial 3: Temática: "Igualdade de Condições"}

Para esta classificação, o critério adotado foi a percepção da mulher como consumidora do produto anunciado, ainda que o termo "igualdade" não seja pleno, considerando que nos comerciais havia elementos de prevalência do universo 
masculino. A peça de 2008 "Antárctica caminhão ${ }^{7 ",}$ exibida durante a pesquisa de recepção, é o retrato dessa representação. Nela, tanto homens quanto mulheres estão em uma mesa de bar, ambos aparecem consumindo a cerveja e tendo uma conversa em que, em algum nível, o teor de igualdade de gênero prevalece. A primeira percepção das entrevistadas foi a suposta igualdade da mulher em relação ao homem, especialmente quanto ao consumo da cerveja, considerando-o emancipatório. As respostas da entrevistada 13 - branca, classe B - "ela está mais independente aí, está compartilhando de um momento com o homem", e da entrevistada 14 - "não branca", classe C - "eu percebi uma coisa que eu consigo ver no dia a dia, que são mulheres bebendo. Homens e mulheres podem beber", ilustram esse consenso.

Interessante mencionar, aqui, que em uma das falas a entrevistada narra que antigamente mulheres não eram aceitas em bares, fazendo-nos refletir sobre o dinamismo das relações sociais baseadas no gênero, descortinando uma sociedade em alguma medida menos opressora para as mulheres que outrora.

Em nossa revisão bibliográfica vimos que na divisão binária de gêneros que alicerça a sociedade há uma clara delimitação daquilo que é "adequado" às mulheres no que se refere ao seu comportamento social. A bebida alcoólica, culturalmente, não pertence a esse universo, tanto que encontramos nas entrevistas falas que reforçavam essas asserções ao mencionar que a sociedade ainda critica a mulher que frequenta bares. A desconstrução dessa percepção que habita o imaginário coletivo é uma forma de alterar, em alguma instância, a hierarquia de privilégios, na qual o homem ainda se encontra no topo.

No entanto, uma parte das entrevistadas alega não participar de grupos de homens, especialmente bebendo, por considerar um comportamento não adequado às mulheres, como afirma a entrevistada 12 - branca, classe B -, "não me vejo em um grupo de amigos homens bebendo cerveja." Poderíamos interpretá-lo como uma "escolha" pessoal ou um estilo de vida. No entanto, não podemos desconsiderar as opressões que são exercidas socialmente, as quais atuam para restringir mulheres dos espaços

\footnotetext{
${ }^{7}$ Disponível em: https://www.youtube.com/watch?v=bhy43kfbNOM
} 
públicos, limitando-as ao privado. Ademais, designam a elas comportamentos apropriados, construídos e alimentados pelo seu entorno - familiar, escolar, religioso, midiático, entre outros. Assim, entendemos que a naturalização do comportamento ideal feminino, sob uma perspectiva hegemônica, também reflete nas mulheres.

De uma maneira negativa, emergiu ao longo da pesquisa o assédio verbal sofrido por mulheres, remetendo, por exemplo, à mulher tratada por "boa" pelos homens; no comercial, o termo foi interpretado por algumas respondentes - especialmente as de classe A e B - como mercantilização do corpo feminino, associando-o à cerveja. Por esse motivo, os homens representados foram considerados machistas.

Quando questionadas sobre o perfil da mulher representada, boa parte das entrevistadas identificou negativamente o perfil da mulher padronizada: "corpão", pelo fato da mulher seguir um padrão de beleza alimentado pela mídia. Ressaltamos que mulheres de todos os perfis mencionaram esse modelo de mulher quando estimuladas, mesmo aquelas que não haviam expressado essa percepção como "primeira impressão". Podemos afirmar que a transformação do corpo em mercadoria no discurso midiático tende a padronizar modelos corpóreos considerados socialmente como ideais. Nesse jogo, as mulheres são levadas a uma eterna insatisfação com sua forma corporal e à busca incessante e inatingível pela perfeição.

\begin{abstract}
A mídia enquanto dispositivo de poder a serviço de uma comunicação baseada nas fórmulas de mercado atualiza constantemente as práticas coercitivas que atuam explicitamente sobre a materialidade do corpo. As subjetividades disciplinadas, preparadas para servir de modo voluntário, levam os corpos a suplícios de forma tão cruel quanto as da Idade Média. Trata-se de um suplício voluntario. 0 corpo mensagem, como corpo da comunicação, mutila-se, modifica-se, transforma-se e estetiza-se para servir como aporte de mercadorias/produtos e de conceitos/ideias (Hoff, 2005, p. 32).
\end{abstract}

Nessa mesma linha, identificamos o perfil da mulher padronizada: branca, já que a mulher do comercial é loira e, nas palavras das entrevistadas, bonita. Notamos que as únicas entrevistadas a mencionarem este aspecto foram mulheres "não brancas". Mulheres autodeclaradas brancas não expressaram qualquer relação entre a beleza das modelos e aspectos étnico-raciais. Longe de ser definida pelo "gosto" ou pela simetria corporal, a beleza é construída a partir de relações de poder. 
Foi à comparação dos sinais do corpo negro (como o nariz, a boca, a cor da pele e o tipo de cabelo) com os do branco europeu e colonizador que, naquele contexto, serviu de argumento para a formulação de um padrão de beleza e de fealdade que nos persegue até os dias atuais (Gomes, 2002, p. 42).

Desse modo, podemos pontuar que a percepção da mulher padronizada (branca) por parte das entrevistadas diz respeito às relações de poder alicerçadas na raça.

\section{Comercial 4: Temática: Objeto}

Para tal codificação, o critério adotado foi a transformação da mulher em objeto de forma explícita e central na narrativa. A peça "Devassa Revista masculina" ", de 2012, é exemplo desse tipo de retratação do gênero feminino. Nele, aparecem alguns homens adorando outro homem, que seria o criador da "primeira revista masculina mais famosa do mundo". Este homem veio ao Brasil decidir quem seria a "Devassa da vez". Para tanto, várias mulheres são expostas para que uma seja escolhida.

A primeira impressão das respondentes foi a exposição exacerbada do corpo feminino para chamar atenção do público masculino, sendo comparada com o produto que estava à venda. Ainda nesse mesmo sentido, algumas entrevistadas apontam ter visto uma desigualdade de gêneros no comercial, uma vez que o homem é retratado como superior e as mulheres inferiorizadas ao seu redor. A resposta da entrevistada 10 - branca, classe C - ilustra esse pensamento: "mais uma vez o homem é o todo poderoso, ele está ali como um rei e as mulheres estão aí só para mostrar o corpo."

Ao perguntarmos se o filme apresentado retrata a vida cotidiana das entrevistadas, essas, em geral, responderam que sim, com respostas bem variadas. Algumas trazem das experiências pessoais o assédio sofrido por mulheres por conta da vestimenta. Essa percepção tem como pano de fundo a sociedade machista, considerando que a mulher não tem direito sobre o seu corpo, como discorrido anteriormente. Entendemos que o machismo também é reproduzido por mulheres, as quais, ainda que vítimas, são impactadas pela ideologia hegemônica. Para reforçar esse

\footnotetext{
${ }^{8}$ Disponível em: https://www.youtube.com/watch?v=Ufj6zNIuSy0
} 
pensamento, apontamos que algumas entrevistadas concordam que certas mulheres se preocupam mais com o corpo e que elas utilizam vestimenta curta para chamar a atenção masculina. Uma delas (entrevistada 9 - "não branca", classe C) relaciona esse comportamento à prostituição, vista de forma negativa. Em suas palavras, "na maioria dos lugares você só vê mulheres se prostituindo".

Para além da exposição do corpo da mulher, este comercial irritou parte das respondentes porque, para elas, o termo "devassa" (nome da marca) se aplicaria às mulheres em geral de forma pejorativa e discriminatória. Pontuamos aqui que as mulheres "não-brancas" demonstraram descontentamento com o fato de todas as modelos serem brancas. Nenhuma das respondentes que se autodeclarou branca mencionou aspectos étnico-raciais, apenas o tipo de corpo considerado "ideal". Mais uma vez temos um padrão de mulheres brancas e loiras como modelo de beleza, o qual exclui mulheres negras. Sobre a lógica do branqueamento, Joel Zito Araújo (2010) reflete como esse fenômeno social se naturaliza nas produções audiovisuais e exclui negros e negras desses espaços.

A internalização da ideologia do branqueamento provoca uma "naturalidade" na produção e recepção dessas imagens, e uma aceitação passiva e a concordância de que esses atores realmente não merecem fazer parte da representação do padrão ideal de beleza do país. (Araújo, 2006, p.77)

Assim, mesmo que não representativo da maioria das mulheres brasileiras, o padrão branco, e preferencialmente loiro, prevalece nesses ambientes, como é o caso deste e dos demais comerciais de cerveja apresentados às respondentes ao longo desta pesquisa.

\section{Comercial 5: Temática: "Protagonista"}

Ainda que esse modelo de representação tenha sido escasso no total de comerciais analisados por Malta e Silva (2016), ele foi considerado para esta pesquisa. Para sua codificação, o critério adotado foi a percepção da mulher como personagem 
principal em determinada ação. A peça "Schin Ivete" , de 2006, é o retrato desse tipo de representação. A cantora Ivete Sangalo aparece cantando em um bar na praia repleto de mulheres consumindo a cerveja. Nesse comercial não há presença masculina.

Ao ser exibido às respondentes, sua primeira impressão foi o protagonismo da mulher. Identificamos que a maioria das mulheres percebeu as personagens como independentes. De maneira positiva, houve aprovação por boa parte das respondentes, sendo interessante mencionar o comentário de uma das entrevistadas ("não branca", classe B), que menciona que o comercial representou "a verdadeira realidade feminina". Por outro lado, houve um estranhamento - de maneira positiva - pelo fato do comercial trazer apenas mulheres, como ilustra o comentário da entrevistada 6 - "não branca", classe A - ao afirmar que o vídeo "colocou a mulher como o centro, é tanto que não tem nenhum homem na peça. Muito raro ver uma peça assim." Provavelmente, este estranhamento advém da baixa frequência desse tipo de representação, além das pressões e opressões sociais as quais sabotam o protagonismo feminino em muitos espaços. Nesse sentido, Woodward (2007) questiona o estruturalismo para discutir os dualismos que alicerçam a sociedade e garantem a permanência de poderes existentes.

Voltando às entrevistas, outras respondentes tiveram uma percepção negativa ao assistirem o vídeo. Uma parte aponta que o protagonismo da mulher ainda se constrói para chamar a atenção do público masculino. Outras apontam ter visto mulheres com perfis parecidos, sendo todas elas brancas de cabelos lisos. Como em vídeos anteriores, notamos aqui que apenas o grupo de mulheres "não brancas" mencionou a presença de mulheres brancas no comercial, o que já foi devidamente discutido.

Ao serem perguntadas se o comercial retratava o seu cotidiano, a maioria das entrevistadas respondeu que sim, pontuando ser comum a saída de mulheres entre amigas para o consumo do produto. É necessário ressaltar que, ainda assim, parte das entrevistadas afirma ser mais frequente a saída de homens entre amigos do que a de mulheres e que o julgamento social influencia esse comportamento, como podemos observar no comentário da entrevistada 7 - "não branca", classe B -: "a sociedade tem

\footnotetext{
${ }^{9}$ Disponível em: https://www.youtube.com/watch?v=h2MDYWTyxRg
} 
mudado, mas acredito que a maior parte acha que a mulher tem que ser mais reservada, que não pode ficar bêbada porque é feio. 0 homem pode, para o homem não é feio".

Observamos, ainda, opiniões no que concerne à presença exclusiva de mulheres no vídeo, com relatos que ressaltam uma suposta "não vulgaridade" da mulher, já que estariam vestidas "de acordo com o ambiente", ou ainda, da "mulher comportada", "sem dar vexame". Novamente identificamos como um modelo de comportamento para a mulher é aculturado na sociedade e se reflete na opinião de algumas entrevistas, sem um olhar crítico.

\section{Comercial 6: Temática: Sedutora}

Para essa codificação o critério foi a representação da mulher que explicitamente seduzia homens. Essa leitura se deu a partir de uma lógica hegemônica - sexista e heteronormativa -, considerando que este processo de sedução está nela alicerçada. 0 que difere tal codificação da mulher objeto é que essa seduz ativamente, e a última é transformada em corpo. A peça do comercial "Itaipava Teste de fidelidade10", de 2013, é o retrato desse tipo de representação. Nessa produção, um homem passa por testes para comprovar sua fidelidade em relação a seus amigos. No último teste, entra em cena a exnamorada de um desses amigos. Trata-se de uma mulher bonita (considerando os padrões midiáticos), que procura seduzir o homem, porém o mesmo resiste e tem a cerveja como prêmio.

A primeira impressão por parte das respondentes foi a percepção da mulher como objeto de satisfação sexual masculina. É importante evidenciar que uma parte das entrevistadas menciona que a mulher foi retratada como inferior à cerveja, uma vez que o homem preferiu a cerveja a ela no comercial. Outra parte justifica ter visto a cerveja como recompensa para a fidelidade à amizade masculina.

Nessa mesma linha, uma das entrevistadas - branca, classe C - relata que é normal o homem ser mais fiel a uma amizade do que a mulher, concordando com a

\footnotetext{
${ }^{10}$ Disponível em: https://www.youtube.com/watch?v=0pfrhq4g89U
} 
narrativa do comercial. Em suas palavras, "homem é muito mais fiel à amizade do que mulher. Porque provavelmente se fosse uma mulher aí já tinha traído a amiga." Ponderamos que essa última observação revela uma das facetas do machismo. Ao recair na mulher o papel de cuidar e manter o matrimônio - da casa, dos filhos, dela mesma e do casamento -, é construída a ideia de que ela tem a obrigação de se manter atraente para o homem. A competição entre mulheres é estimulada, resultando no estigma de que mulheres não são boas amigas.

Somente uma entrevistada aponta ter se sentido totalmente confortável ao assistir ao vídeo, pois, para ela, a mulher assume um papel de poder, já que o homem tenta resistir às suas seduções e, assim, se posiciona como submisso a ela. De maneira oposta, uma respondente interpretou o homem como superior, possuindo o poder de avaliar, escolher ou dispensar uma mulher.

As demais respostas muito se assemelham aos aspectos encontrados em vídeos anteriores, relacionados à exposição do corpo da mulher, sua objetificação e mercantilização, assim como à padronização de um modelo de beleza excludente e racista.

\section{Comercial 7: Temática: "Segundo Plano"}

Para essa temática o critério aplicado foi a constatação de que a mulher é preterida, sempre sob a lógica heteronormativa. A peça "Brahma Futebol"11, de 2012, é exemplo desse tipo de representação e foi exposta às entrevistadas durante a pesquisa de recepção. Na produção, homens estão em um estádio de futebol fazendo uma homenagem para a cerveja, e suas supostas mulheres, que estão assistindo ao jogo em casa, pela TV, pensam, em um primeiro momento, que a homenagem é para elas. Quando se dão conta, tomam toda a cerveja da geladeira. Na última cena, elas afirmam que consumiriam "a cerveja deles" como forma de vingança.

\footnotetext{
${ }^{11}$ Disponível em: https://www.youtube.com/watch?v=9B0bW1b4pz0
} 
Como primeira impressão, foi apontada a "proibição" (ou não recomendação) do consumo do produto para as mulheres. Observamos, ainda, a associação do homem ao futebol e à cerveja e quase um consenso ao afirmar que a mulher, assim como na narrativa, é preterida na vida real, como na fala da entrevistada 12 - branca, classe B -: "a maioria dos homens dá mais valor à cerveja e deixa a mulher de lado". Por fim, pontuamos a percepção positiva de algumas respondentes por conta da vingança da mulher ao consumir a cerveja, expressando uma característica de não "delicadeza" da mulher, o que poderia ser lido como contra-hegemônico.

A maioria das entrevistadas notou o homem como público-alvo do produto, uma vez que o consumo da cerveja por parte da mulher no comercial foi rotulado como "proibido" pelas próprias respondentes, como se a cerveja não fosse para elas. A fala da entrevistada 4 - branca, classe C - é exemplo deste pensamento: "acho que talvez o que tenha me incomodado mais foi que parece que cerveja é um produto só para homem. E o fato delas falarem 'vamos beber a cerveja deles', parece que é algo proibido para elas". É importante mencionar que estas respondentes percebem a sociedade como recriminadora desse tipo de comportamento.

Sobre aspectos do cotidiano, as entrevistadas, em geral, narraram ser comum o homem sair de casa e a mulher permanecer nela e, nesse sentido, uma entrevistada menciona acontecer isso em sua própria casa. Encontramos, aqui, suporte empírico para a discussão teórica acerca do patriarcado que ainda se faz presente na sociedade, coagindo as mulheres a ocuparem determinados espaços e restringindo-as de outros.

$\mathrm{Na}$ antropologia, com base nas asserções de Henrietta Moore (1994), as desigualdades de gênero são compreendidas a partir de duas perspectivas. A primeira está associada à constante identificação das mulheres com a natureza e dos homens com a cultura. A segunda, alicerçada nas estruturas sociais, relaciona a mulher à esfera privada, do lar e das relações pessoais, e o homem à esfera pública, produção e comércio, política, as relações sociais mais complexas. Este conteúdo audiovisual retrata a divisão social proposta por Moore. Ao discutir sobre tais papéis, ainda que o vídeo não o explicite, algumas respondentes relataram que a mulher é mais "sentimental e 
delicada" que o homem por conta dos hormônios. Esta última resposta desperta a necessidade de se problematizar a perspectiva essencialista a qual define que aspectos biológicos e fenotípicos, cristalizados e estáticos, determinam as identidades e, consequentemente, os papéis sociais. Propomos a desconstrução deste pensamento ao nos basearmos nos Estudos Culturais.

As chamadas interpretações biológicas são, antes de serem biológicas, interpretações, isso é, elas não são mais do que a imposição de uma matriz de significação sobre uma matéria que, sem elas, não tem qualquer significado. Todos os essencialismos são, assim, culturais. Todos os essencialismos nascem do movimento de fixação que caracteriza o processo de produção da identidade e da diferença. (Silva, 2007, p.86)

Assim, a interpretação do biológico não é aleatória, mas estruturada em relações de poder que favorecem o patriarcado. Se os essencialismos foram constantemente questionados por algumas entrevistadas ao longo desta pesquisa de maneira crítica, por outras, alguns de seus aspectos foram reforçados.

\section{Considerações finais}

Para uma discussão fundamentada acerca da representação da mulher na publicidade brasileira destinada à cerveja, partimos da premissa de que os sistemas simbólicos de representação, como os midiáticos, são importantes para o reconhecimento identitário. Nesse contexto, existem diferentes relações de dominação e poder que estruturam a sociedade, tais como as alicerçadas no gênero, na etnia e raça ou sexualidade, as quais encontram, ou não, espaço nessas arenas.

Baseando-nos no estudo apresentado em Malta e Silva (2016), concluímos que a bebida alcóolica ainda é um produto destinado ao público masculino, e mesmo a mulher ganhando destaque em alguns comerciais de cerveja, a sua aparição como consumidora ainda é modesta, prevalecendo uma representação estereotipada que a caracteriza 
conforme o imaginário masculino. Vale ressaltar que o consumo de bebidas alcoólicas por mulheres brasileiras está em constante ascensão, como demonstra o relatório da OPAS - Organização Pan-americana da Saúde - (OPAS, 2018), e que a cerveja é classificada, entre as bebidas, como a preferida por elas.

Por meio do estudo de recepção, realizado com mulheres jovens da cidade de Aracaju, concluímos, de modo geral, que mesmo as mulheres se assumindo consumidoras do produto e independentes, elas enxergam que tanto a sociedade - pelo reconhecimento de que o consumo de álcool por mulheres ainda é alvo de críticas quanto a publicidade direcionam esse produto para o público masculino, o que as incomoda.

Notamos, também, que embora algumas mulheres sintam-se indiferentes às narrativas, ou concordem com as mesmas - retrato da naturalização e aculturação da ideologia hegemônica -, a maioria delas não se sente confortável ao se deparar com o conteúdo midiático apresentado. Evidenciamos que em todos os casos a pesquisa de recepção confirmou o modelo de representação identificado em Malta e Silva (2016) e o ampliou, reconhecendo formas de representação, por vezes implícitas, as quais não haviam sido consideradas como significativas pelo estudo.

Concluímos ainda que, ao exibirmos a mulher como protagonista em um dos comerciais, a maioria das entrevistadas se identificou com essa representação. Todavia, quando foram apresentadas a comerciais os quais retratavam a mulher de forma estigmatizada sob a lógica da objetificação e mercantilização, a insatisfação entre a maioria ficou explícita. A representação uníssona no que diz respeito ao corpo e ao modelo de beleza das mulheres também gerou uma insatisfação maior por parte das entrevistadas não brancas, e mais intensamente por aquelas pertencentes às classes $\mathrm{C}$ e D, especialmente devido a não representação de mulheres de outras raças, além da branca, nos comerciais. Reconhecemos nesse resultado uma relação de poder baseada na classe e raça, a qual oprime mulheres negras e pobres, invisibilizando-as nos sistemas simbólicos de representação, como é o caso da publicidade. 
No início deste artigo consideramos como pergunta norteadora em que medida o construto social representado na publicidade (como mediadora) se reflete na percepção das respondentes. Ao observar o incômodo gerado pelo conteúdo apresentado, pontuamos que para este grupo - mulheres jovens - os modelos de representação não geram autorreconhecimento e produzem rechaço.

Concluímos, assim, que o público-alvo destas produções publicitárias, em geral, não inclui mulheres, o que não condiz com os resultados das pesquisas acerca do consumo de bebida alcóolica por parte das mulheres, como bem pontuamos. É importante ressaltar, por fim, o período em que a seleção do corpus foi realizada. Os anúncios analisados em Malta e Silva (2016), base para a seleção do material exposto às respondentes, foram produzidos e veiculados antes da data de publicação do artigo (entre 2004 e 2013). Desde então, algumas mudanças sociais expressivas foram motivadoras de um novo posicionamento por parte de algumas marcas de cerveja, expresso em suas ações comunicacionais. A Skol, por exemplo, declarou em seu canal no Facebook no dia 08 de março de 2017 - dia Internacional da Mulher - que "já faz alguns anos que algumas imagens do passado não nos representam mais", assumindo o conteúdo machista de suas produções e firmando um compromisso de mudança. De fato, os últimos anos foram marcados por produções mais plurais no que concerne a representação de gênero. Certamente as críticas por parte dos movimentos sociais feministas exerceram influência, somadas ao rechaço por parte das mulheres - como demonstrou esta pesquisa. Nesse jogo, o interesse mercadológico prevalece, já que mulheres brasileiras bebem cerveja - e cada vez bebem mais. Ainda assim, outras marcas de cerveja permanecem centradas em uma comunicação voltada ao público masculino e, sob a perspectiva machista, objetificam e mercantilizam corpos femininos para atender esse mercado. Entendemos que outras pressões ainda precisam se fazer presentes, e é nesse sentido que este artigo ganha relevância social, para além da acadêmica. 


\section{Referências bibliográficas}

ARAÚJO, Joel Zito et al. (Orgs.). O negro na TV Pública. Brasília: FCP, 2010.

BAUER, Martin \& GASKELL George. Pesquisa Qualitativa com Texto, Imagem e Som. Petrópolis: Editora Vozes, 2002.

CERTEAU, Michel de. A Invenção do Cotidiano. Petrópolis: Editora Vozes, 1998.

CRENSHAW, Kimberlé. Documento para o encontro de especialistas em aspectos da discriminação racial relativos ao gênero. Estudos Feministas, Florianópolis, v. 10, n. 1, p. 171- 188, jan. 2002.

DAVIS, Angela. As Mulheres Negras na Construção de uma Nova Utopia. Conferência realizada em 13 dez. 1997, São Luís. I⿳ạ Jornada Cultural Lélia Gonzales. Disponível em: arquivo.geledes.org.br/atlantico-negro/movimentos-liderespensadores/afroamericanos/10243-as-mulheres-negras-na-construcao-de-uma-novautopia-angela-davis. Acesso em 12 dez 2018.

DUARTE, Jorge. Entrevista em profundidade. In: DUARTE, Jorge \& BARROS, Antonio (Ed.). Métodos e técnicas de pesquisa em comunicação. São Paulo: Atlas, 2006. p. 62-83.

GOMES, Nilma. Trajetórias escolares, corpo negro e cabelo crespo: reprodução de estereótipos ou ressignificação cultural? Revista Brasileira de Educação, n. 21 Set-Dez. 2002. P.40-51.

HALL, Stuart. Da Diáspora: Identidades e mediações culturais. Belo Horizonte: Editora UFMG, 2003.

HOFF, Tania. O corpo imaginado na publicidade. Cadernos de Pesquisa ESPM. São Paulo: ESPM, n. 1, v. 1, mai./jun. 2005, p. 9-64.

HOOKS, bell. Intelectuais negras. Revista Estudos Feministas, v.3, n. 2, 1995, p.464-478.

KELLNER, Douglas. A cultura da mídia. Estudos culturais: identidade e política entre o moderno e o pós-moderno. Bauru: EDUSC, 2001.

MALTA, Renata; SILVA, Kivia. A atual representação da mulher em comercias de cerveja: relações socioculturais e mercadológicas. Verso e Reverso, v.30, n.73. Jan-abr. 2016, p. 50-57.

MARCONDES, Mariana et al. (Ed.). Dossiê mulheres negras: retrato das condições de vida das mulheres negras no Brasil. Brasília: IPEA, 2013.

MOORE, Henrietta. Divided we Stand: Sex, Gender and Sexual Difference. In: Feminist Review, n. 47, 1994, p. 78-95. 
ONU MULHERES. Salvador, Natal e Fortaleza lideram ranking de violência física contra as mulheres no Nordeste, 23 nov. 2017. Disponível em http://www.onumulheres.org.br/noticias/salvador-natal-e-fortaleza-lideram-rankingde-violencia-fisica-contra-as-mulheres-no-nordeste/. Acesso em 15 jun. 2019.

OPAS - Organização Pan-americana da Saúde - Folha informativa: Álcool. 2018. Disponível em: https://www.paho.org/bra/index.php?option=com_content\&view=article\&id=5649:fol ha-informativa-alcool\&Itemid=1093. Acesso em 01 mar. 2019.

PACHECO, Ana Cláudia. Mulher Negra: Afetividade e Solidão. Salvador: ÉDUFBA, 2013.

PIEDRAS, Elisa. A transformação da publicidade em diferentes contextos socio-históricos no Brasil: Análise de peças publicitárias como testemunhos culturais. Grupo de Trabalho História da Publicidade e Propaganda, Universidade Federal de Santa Catarina, 2005. Disponível em: www.jornalismo.ufsc.br/redealcar/cd3/pp/elisareinhardtpiedras.doc. Acesso em: 28 ago. 2017.

ROCHA, Everardo. Magia e capitalismo: um estudo antropológico da publicidade. 2.ed. São Paulo: Brasiliense, 1990.

RUÓTOLO, Antonio. Audiência e recepção: perspectivas. Comunicação e Sociedade, São Bernardo do Campo, n. 30, 1988, p. 159-170.

SILVA, Tomaz Tadeu. Identidade e diferença: a perspectiva dos estudos culturais. In: SILVA, Tomaz Tadeu (Ed.) Identidade e diferença: a perspectiva dos Estudos Culturais. 7ạ Ed. Petrópolis : Vozes, 2007, p. 73-102.

WILLIAMS, Raymond. Marxismo e literatura. Rio de Janeiro: Zahar, 1979.

WOODWARD, Kathryn. Identidade e diferença: uma introdução teórica e conceitual. In: SILVA, Tomaz Tadeu (Ed.) Identidade e diferença: a perspectiva dos Estudos Culturais. 7ạ Ed. Petrópolis: Vozes, 2007, p. 7-72. 